\title{
Allan Fenigstein \\ Were Obedience Pressures A Factor in the Holocaust?
}

\begin{abstract}
A number of scholars have suggested that Milgram's laboratory studies of obedience offer an incisive analysis of the behavior of the Holocaust perpetrators. The present paper rejects that position. The contrasts between the two events, at every level of analysis, are striking: In Milgram's research, innocent peers were harmed in the context of science; in the Holocaust, rabidly hated, subhuman enemies were murdered in the context of 'war'. With regard to underlying psychological mechanisms, the evidence questioning the relevance of Milgram's research is equally compelling: obedience pressures had little role in the Holocaust. Most of the Nazi perpetrators showed no remorse or moral distress over the murders and perhaps most critically, virtually all of the killers knew that they could choose not to participate in the killings.
\end{abstract}

Milgram's (e.g. 1963; 1974) remarkable laboratory studies on obedience to authority have achieved their enduring impact and visibility, not only because of their unexpected findings - which challenged some of our most basic and cherished notions about the human capacity for evil, but also because of their apparent ability to shed light on questions raised by an event in human history - the Holocaust - that has sometimes been regarded as utterly incomprehensible: How do we make sense of the behavior of Nazi murderers and their collaborators who actively participated, on a massive scale, in carrying out the systematic extermination of most of European Jewry? ${ }^{1}$

From the inception of his studies of obedience, Milgram framed the project in the context of the Nazi extermination policy (Miller/Collins/Brief 1995). According to Milgram, the 'Final Solution' could not have been carried out unless a great many Nazis obeyed orders; that is, obedience to authority was the underlying psychological mechanism that explained how otherwise ordi-

1 Although the Nazis murdered millions of other innocent victims, the nature of Nazi crimes against the Jews was both qualitatively and quantitatively different from the crimes committed against other victim groups. Different psychological analyses may apply to similar crimes against different targets; because the focus of this paper is on Jewish victims of Nazism, the use of the term "victim" will imply only Jewish victims. Similarly, the use of the term "Nazi" is intended to refer to all those who participated in the Nazi extermination program against the Jews, including non-German collaborators.

Analyse \& Kritik 20 (1998), S. 54-73 든 Westdeutscher Verlag, Opladen 
nary Germans became capable of destroying the lives of millions of innocent Jews. For Milgram (1974), the focus and abiding legacy of his research program was in demonstrating the ease with which destructive obedience- that is, obeying orders to seriously injure or kill innocent victims, in spite of powerful moral or emotional resistance to those actions-could be elicited from seemingly normal persons.

Although other scholars and researchers have accepted, at least in part, Milgram's analysis of the Holocaust (e.g. Bauman 1989; Berger 1983; Darley 1992; Kelman/Hamilton 1989; Miller 1986; Sabini/Silver 1980), the present paper rejects that position. Instead, it attempts to identify a number of critical conceptual problems ${ }^{2}$ that seriously undermine the notion that parallels can be drawn between the behavior of Milgram's subjects and those of the Nazi torturers and murderers. Ultimately, it will be argued, these problems warrant the conclusion that Milgram's research has little, if anything, to say about the behavior of the perpetrators of the Holocaust.

\section{The Milgram Studies}

We begin with a brief description of the classic Milgram research paradigm: Milgram (1963) asked ordinary, mentally healthy subjects, ${ }^{3}$ drawn from a broad spectrum of socioeconomic and educational backgrounds, to participate in a study on the psychology of learning. These subjects, acting as 'teachers', were to administer punishment-in the form of increasingly severe electrical shocks - to another participant, the 'learner', whenever the learner failed to answer a question correctly. Although each teacher submitted to a low level, but quite unpleasant, sample shock (in order to heighten the realism of the situation), no other shocks were actually delivered during the experiment. But the teacher did not know that; for the teacher, the situation was extremely realistic and tension-provoking. As the supposed shocks grew increasingly intense, the learner/victim's prerecorded reactions became more excruciating. Early in the procedure, the victim shouted that the shocks were becoming too painful. That was soon followed by a demand to be let out of the experiment. Next the victim cried out that he could no longer stand the pain. Eventually, he began yelling that he would not provide any more answers and insisted that he be freed. Over the course of the next set of shocks, there were

\footnotetext{
2 Methodological problems concerning Milgram's research-for example, whether Milgram's subjects' really believed they were injuring another person (e.g. Mixon 1976), or whether there is a plausible alternative to the 'obedience to authority' explanation for their destructive behavior, such as 'demand characteristics' (e.g. Orne/Holland 1968) - are not at issue in the present analysis.

3 The great majority of Milgram's subjects were male, as were the great majority of Nazi perpetrators, and so references to these persons throughout the paper will use the male pronoun forms.
} 
agonized screams and, finally, silence. In trying to decide what to do during the experiment, many subjects turned to the experimenter/authority for direction or instruction. The response, using a number of different verbal prods, was simple and direct: the experiment must continue and the experimenter would take 'full responsibility'.

How far did subjects go in obeying the experimenter? The now well-known and still startling finding was that about $65 \%$ of the subjects were willing to punish another person with an almost lethal dose of electric shock, despite the fact that the victim did nothing to merit such severe punishment, and that the experimenter had no special powers to enforce his orders. ${ }^{4}$ Much of the fascination that attends to Milgram's studies derives from the lessons it implies about the nature of evil, that is, about how easily ordinary individuals, possessing no hostility or malevolence, can carry out terribly destructive, inhumane commands. Another implication that some scholars (e.g. Askenasy 1978; Charny 1982; Lifton 1986; Sabini/Silver 1980) have drawn is that anyone- not just Nazis and their collaborators and sympathizers-could have participated in the nearly-successful annihilation of the Jewish people.

\section{Relevance to the Holocaust}

Almost immediately after they were published, the obedience studies were criticized as being too dissimilar from Nazi Germany to warrant generalizations (e.g. Baumrind 1964). Even Milgram (1974), as well as others who shared his perspective (e.g. Browning 1992), recognized that there were enormous disparities in circumstances and consequences between the artificial laboratory situation of the obedience studies, and the all-too-real horrors of Nazi Germany (see below). Nevertheless, Milgram argued that the plausibility of extrapolating from the laboratory to the real world depends, not so much on a detailed point-by-point comparison between the surface features of the two events, but rather on the comparability of the underlying explanatory mechanism. Despite the apparent differences in the situational details, Milgram believed that a similar psychological process-essentially, a predilection toward obedience - was centrally involved in both his laboratory studies and the Holocaust.

Following Milgram's lead regarding the distinction between surface features and underlying processes, the largely noncontroversial question regarding the lack of comparability of the situational details will first be briefly addressed. Although there is considerable consensus on this issue, it will be argued that the importance of these dissimilarities to the question of gener-

\footnotetext{
${ }^{4}$ Subsequent studies have shown this finding to be reasonably reliable (see reviews by Blass 1992; Miller 1968).
} 
alizability may not be as easily dismissed as Milgram suggested. Next the more contentious, and arguably more critical, question regarding the degree of correspondence between the basic psychological processes operating in the two situations is examined.

\section{Comparing the External Situational Features}

As suggested previously, virtually everyone, including Milgram, has acknowledged enormous differences between the specific situations of Milgram's laboratory in the early ' $60 \mathrm{~s}$, and the killing fields of Central Europe in the early ' $40 \mathrm{~s}$; it is a relatively easy task to catalog these very concrete, observable, and sometimes painfully obvious differences.

Cultural context. Milgram's subjects were college students participating in psychological research, and presumably contributing to science, under the auspices of an academic institution dedicated to the welfare and betterment of all humankind (including the experimental victim).

Nazi murderers were participating in what was considered to be a "war against the Jews" (Dawidowicz 1975), even though their victims were totally defenseless, under the auspices of a dictatorship that was singularly dedicated to the extermination of its Jewish "enemies".

Actions performed. Milgram's subjects were pushing buttons that they firmly believed were delivering painful, and potentially dangerous, shocks to the victim. However, subjects received repeated assurances from the authority that no permanent physical harm or injury would be inflicted on the other person. Thus, even if the subject thought that the victim might be hurt, there likely was some doubt or uncertainty regarding the outcome of their actions, especially considering what some observers regard as a tacit understanding, in addition to the explicit promises given, that the experimenter would not allow the subject to engage in dangerous or harmful behavior (e.g. Mixon 1979; Orne/Holland 1968).

Nazi perpetrators knew, without question, that they were murdering their victims.

Clarity vs ambiguity of the situation. The question of certainty or confusion also extends to an understanding of the larger situation. Ross and Nisbett (1991) have argued that in many ways, much of what was going on in the Milgram study simply did not make any sense to the subjects; e.g., at one point, they had to continue to interact with a totally silent, nonresponsive learner/victim; and throughout the study, the experimenter seemed absolutely (and curiously) oblivious to the cries of anguish of an innocent research participant. In the face of this chaos and confusion, it may be understandable that subjects became indecisive and highly dependent on a calm and confident authority issuing orders. 
In contrast, given the very clear and well-defined 'military' operation before them, the powerful indoctrination preparing them for the task, and the frightening orderliness and efficiency of the killing process, it is unlikely that the perpetrators experienced any uncertainty as to why the other people around them were behaving as they were.

'Gradualness' of harmdoing. Milgram's subjects initially used very low, harmless levels of shock, and only gradually did the intensity of the shock increase. This may have created a sense of psychological entrapment or dissonance for the subject during the course of the experiment (e.g. Gilbert 1981).

For many of the killers, even if considering only their first encounter with a victim, the act of killing came about quickly. If there were any preliminary activities, they often involved the humiliation, degradation, or brutalization of the victim (Dawidowicz 1975; Goldhagen 1996).

Relationship to victim. Milgram's subjects thought that they were delivering potentially injurious shock to other experimental subjects who were their peers.

In Nazi Germany, innocent Jewish victims (including infants and children) had been systematically devalued to the point where their lives were considered to be 'unworthy of life'. Centuries of antisemitism, a decade of legalized discrimination, and an intense, unrelenting onslaught of vicious, hateful propaganda depicting Jews as vile enemies, intent on domination, exploitation, and victimization of the German people, had allowed many Germans to remove Jews from the circle of human obligation, ultimately preparing the perpetrators to accept, and perhaps even welcome, the vilification and eventual destruction of the Jews.

Relationship to authority. The pressures to obey authority in the Milgram study derived, not from any power the experimenter had to reward or punish the subject, but rather from the experimenter's 'legitimate' position as a trusted, expert scientist (see Aronson/Brewer/Carlsmith 1985). That legitimacy, however, not only conveyed an obligation on the part of the subject toward cooperation and obedience, it also involved responsibility, on the part of the experimenter, for the safety and well-being of the research participants. The dual role of the experimenter/authority, pressuring the subject's behavior toward the learner in two different directions, may help to explain why subject/teachers displayed a great deal of resistance, questioning, and hesitation in response to the experimenter's instructions; there was little indication of any 'absolute' obedience.

In addition to the legitimate authority of commanding officers, superior officers in a military hierarchy can also expect obedience from their subordinates by virtue of their coercive power. Thus, there is every reason to expect unquestioning, absolute obedience in a military operation such as the Holocaust, and that has been the operating assumption for many scholars (see, 
e.g. Miller 1986). Interestingly, however, the extent to which the killing of innocent Jews was absolutely demanded from Nazi soldiers has been seriously questioned (e.g. Goldhagen 1985). The critical issue for the moment, however, is that the nature of authority, and the subordinate's relation to that authority, were markedly different in the two situations.

Perhaps more importantly, in contrast to the Milgram studies, the Nazi killer's act of destroying the victim was in no way countermanded; as noted by Baumrind (1964), Nazi perpetrators had no reason to believe that their superior officer had any concern for the well-being of the victim.

Intensity of authority pressure. Based on postexperimental interviews with laboratory subjects, as well as observations made during their participation, it may be argued that subjects were faced with an ethically unacceptable high level of obedience pressure directing them to physically harm an innocent other (Baumrind 1964).

The intensity of this pressure may stand in ironic, yet significant, contrast to the experience of the perpetrators in Nazi Germany. As noted above (and discussed in more detail below), one of the most remarkable aspects of the authority-subordinate relationship operating among the perpetrators of the Holocaust was the extraordinary lack of pressure emanating from superior officers when asking for (rather than demanding) the participation of subordinates in the slaughter of Jews.

Inter-individual vs intergroup perspectives. The Milgram studies may be seen as focusing almost exclusively on the attitudes and behaviors of people as individuals; that is, the paradigm is an attempt to understand how any person, regardless of their background, personality, or group identity, would respond to authority pressures to hurt another person who, again, could be anyone.

In contrast, the attempted annihilation of the Jews by the Nazis, involved the actions of individuals as group members, and must be fundamentally understood and analyzed as an intergroup phenomenon. The Holocaust, as an event, is not only historically defined in terms of Nazis and Jews, but was experienced in those same terms by the victims and the perpetrators. As a result, a psychological understanding of the behavior of the Nazi murderers must take on a fundamentally different focus of analysis: the thoughts, feelings, and actions of the perpetrators as a whole may have been much more a matter of their shared group identity as Nazis than a matter of their individual characteristics (e.g. Fenigstein 1998). 


\section{Can 'Surface' Differences be Dismissed?}

Milgram acknowledged a multitude of circumstantial and behavioral differences between his subjects and those of the Nazi murderers, but dismissed those differences as largely irrelevant to the issue of generalization. This dismissal is especially puzzling in view of the fact that Milgram's own research program demonstrated, in a compelling fashion, the extent to which obedience in the laboratory was influenced by subtle experimental, i.e., situational, details, such as the distance between the principals, or the presence of other subjects (see, e.g. Blass 1992; Miller 1986; Ross/Nisbett 1991). How, then, can the situational differences enumerated above simply be ignored?

Milgram's response, in effect, is that the important question, as to whether the obedience studies offered any insight into the psychology of the Holocaust perpetrators, is in the comparison of (what he considered) the more critical, core psychological processes operating in the two situations. Before turning to the question of core processes, however, it may be appropriate to ask whether Milgram's dismissal of the relevance of 'surface' differences is warranted. To some extent, it may be, in that appearances may be deceiving. That is, although two events may look different, it is certainly possible that similar underlying processes are at work; but before assuming that possibility, some rational basis for it must be found.

Given the vast differences in time and place, and the obvious dissimilarities, not only in their specific details, but in the enormity of the events under discussion, why would anyone, including Milgram, assume that the underlying psychological processes involved in the obedience studies were similar to those of the Nazi perpetrators? Because, as Milgram (1974, 175-8) explained, there were some recognizable similarities between the two events: In both cases, innocent victims were being hurt; the agents of harm were apparently ordinary persons who were, at the time of the harmdoing, subordinates in a hierarchical relationship; and an authority figure was present or in close proximity.

What is being suggested is that Milgram's (and other's) assumptions regarding a relationship between his research and the Holocaust, may very well have been based on an extremely selective consideration of the 'surface' features of the two events. That is, Milgram may have assumed an underlying psychological correspondence because he focused on certain elements of the two events which suggested some underlying similarity; when considering dissimilar elements of the two events, however, he simply dismissed those features as irrelevant to the question of underlying processes. The question, of course, is whether the similarities he emphasized are any more relevant or crucial to the question of core psychological mechanisms than the dissimilarities he dismissed as superficial and irrelevant.

In addition to this highly selective examination of the 'surface features' of 
the two events, Milgram may have been guilty of ignoring a logical corollary of the above-cited injunction regarding surface appearances, namely: although two events may look the same, it is certainly possible that different underlying processes are at work. That is, the surface similarities that Milgram noted between the obedience studies and the Holocaust may themselves be superficial and misleading (as will be argued in greater detail below), and therefore of little value in determining whether there is a correspondence in the core psychological processes.

\section{Interim Conclusion}

When arguing for a connection between his obedience studies and the Holocaust, Milgram maintained that the glaring disparities in the external features of the two events should be ignored, precisely because they are 'external', that is, irrelevant to the question of more basic processes. That argument, however, loses credibility when one considers that the reasoning Milgram used to support the generalizability of his research to real world Nazi horrors depended, in all likelihood, on precisely the same kind of 'external features'. If a judgment about the validity of generalization is to be based purely on the comparability of external appearances, and those appearances involve suggestive similarities, as well as striking differences, both of relatively equal significance, then the evidence must be considered inconclusive, and it would be remiss to assume any connection between the obedience studies and the Holocaust.

\section{Comparing the Underlying Psychological Mechanisms}

Milgram, in arguing for the possibility of similar explanatory processes, despite differences in the surface appearance of two events, used the analogy of "a match flame" as comparable to "the Chicago fire of 1898" (Milgram 1974, 175). In that case, although there are obvious differences in the magnitude of the two events, a strong case can be made, based on firmly established natural laws and virtually indisputable evidence, that an identical mechanismcombustion - was operating in both cases.

The match-fire analogy, however, seems entirely inappropriate to the correspondence Milgram claimed between the psychological mechanisms operating in his obedience studies and those that explain the actions of Nazi murderers during the Holocaust. The difficulty is that questions are now being asked, not about observable and easily verifiable physical events, but rather about 
unobservable intentions, motives, thoughts, and feelings. An additional concern is that whatever information is available about these mental events is subject to deception, denial, misrepresentation, and misinterpretation. Thus, considerable caution needs to be exercised in making inferences about, and comparisons between, the psychological motives of Milgram's subjects and those of the perpetrators.

With that caveat in mind, let us proceed. Milgram's (1974) argument for a common psychological mechanism actually involved two different levels of analysis. At a macro-psychological level, he suggested that the essence of destructive obedience involves a situation in which a person is ordered by a legitimate authority to harm a third person; that, he asserted, is the fundamental situation that confronted both his subjects and the Nazi perpetrators. At a micro-psychological level, the specific mechanism that Milgram posits to explain obedient behavior, both in his experimental subjects and in the Holocaust perpetrators, is the agentic state, in which subordinates relinquish a sense of personal responsibility for their behavior and become thoughtless agents of action. Problematic questions exist with respect to both levels of analysis.

\section{The Agentic State}

Milgram argues that ordinary persons, as a result of their socialization history, become well practiced in adopting the mentality of an agent who, in an essentially mindless fashion, performs an action that is authorized by someone else. The most far reaching consequence of this submission to authority is an "extraordinary psychological transformation", in which a sense of conscience or responsibility for one's actions disappears. All initiative is attributed to the authority, and the obedient subject, as well as the Nazi perpetrator, sees himself simply as an instrument of the authority, and in no way morally accountable for his actions. This "agentic" state, for Milgram, is not merely a thin alibi; it represents a fundamental change in the individual's mode of thinking and self-understanding.

This perspective certainly has some appeal, particularly as it relates to the Nazi murderers. The concept of the agentic state is frighteningly evocative, for example, of the litany of "I was just following orders" heard repeatedly at the Nuremberg trials. Although Milgram argued that these defense claims actually represent serious and significant psychological truths, the possibility that these men were simply trying to avoid or mitigate punishment for their crimes, must obviously be considered (as the Nuremberg jurists, in fact, often did). Thus, it is difficult to find convincing evidence for the agentic state by examining the testimony (or psychiatric protocols, e.g. Lifton 1986) of war criminals. 
Another, more rigorous, means of assessing the validity of the agentic state, is through controlled research which attempts to determine whether experimental subjects, who have complied to the demands of an authority, are prepared to simply "give away" responsibility for their behavior. In general, the research has not offered a great deal of support for the idea of an agentic "shift" in responsibility (e.g. Blass 1992; Miller 1986). Milgram (1974) himself, contrary to the predictions of his own theory, found that obedient subjects attributed just as much responsibility for their behavior to the experimenter as did subjects who defied the experimenter's demands. Similarly, other studies (e.g. Mantell/Panzarella 1976; Tilker 1970) have shown essentially no relationship between the subjects' degree of obedience to the authority, and their assignment of responsibility for their behavior. In general, the research findings seriously challenge the explanatory value of an 'agentic' state which involves the easy removal or denial of responsibility for one's own immoral actions. Given the empirical weakness of this concept, it would be difficult to argue, at least at the micro-psychological level, that Milgram's conception of the mental state of his laboratory subjects has any relevance to the Holocaust.

\section{Obedience and the Perpetrators}

Moving on to the macro-psychological level, there is little question that "obedience to authority" defines the essence of the laboratory situation that Milgram studied. But-and this is the key issue - does obedience, in this case to the demands of a military authority to kill Jewish victims, also constitute an essential element of the behavior of the Nazi murderers?

Milgram was not the only scholar to assert that the Nazi perpetrators murdered out of a sense of duty or diligence or the demand to obey. Others, most famously Arendt (1963), offered essentially the same position. Arendt's notion of the "banality of evil", claiming that Nazi henchmen like Adolf Eichmann were little more than uninspired bureaucrats simply doing what they were told, was seen by Milgram as a powerful confirmation of his argument that mindless, but dutiful, obedience was guiding the behavior of Nazi murderers.

A cursory examination of the evidence, however, raises troubling doubts about any parallels between Eichmann and Milgram's subjects. The subjects were, in many ways, not like Eichmann; they did not act like mechanistic bureaucrats. Almost everyone in the research experienced great tension, distress, and conflict while shocking the victim. In contrast, Eichmann showed no corresponding difficulty in carrying out his orders. That is, on the basis of how they acted when hurting others, there is little reason to believe that the behavior observed in laboratory subjects involved the same psychological processes guiding someone like Eichmann. 
Their behavior may have differed, however, not because of a lack of correspondence in the underlying processes, but rather because of critical differences in their two situations. Eichmann only had to sit at his desk to participate in mass murder. He rarely experienced, in any direct, personal way, the consequences of his actions (but when he did, touring the concentration camps, even he was sickened). The subjects in Milgram's experiment, on the other hand, were given graphic and immediate confirmation of the effect of the shocks they were administering. These circumstantial differences could easily account for the different emotional responses.

Perhaps a more appropriate test of corresponding psychological mechanisms would be a comparison of Milgram's laboratory findings with the behavior of the Reserve Police, whose men confronted the effects of their actions in an extremely direct and explicit way-they literally became "saturated in the blood of their victims" (Browning 1992). Browning, in evident agreement with Milgram's analysis, felt that although none of Milgram's studies exactly paralleled the historical situation of Nazi Germany, "nonetheless many of Milgram's insights (regarding obedience) find graphic confirmation in the behavior and (subsequent) testimony of the men of Reserve Police Battalion 101 " $(1992,174)$, who carried out shootings and deportations to death camps of thousands of Jewish victims.

Relying extensively on Milgram's research and theoretical analyses, Browning argued that pressures to obey the directives of authority, "even to the point of performing repugnant actions in violation of 'universally accepted' moral norms" (171), were an important influence in explaining how the "ordinary men" of Reserve Police Battalion 101 became active participants in mass murder. At one point, he even suggests that the massacre these Police carried out one day at Józefów where 1500 men, women, and children were systematically slaughtered by gunfire, might have been "a kind of radical Milgram experiment that took place in a Polish forest with real killers and victims" (173-4).

It is hard to imagine a more emphatic endorsement of Milgram's studies as directly applicable to the Holocaust. But one needs to be careful in accepting this analysis by analogy. There is no question that when faced with orders to commit atrocities, the policemen carried out those atrocities. That is, based merely on surface appearances, it would seem as if the perpetrators obeyed orders. But looks may be deceiving, and it is necessary to ask whether, despite the appearance of obedience, there are alternative, and perhaps more valid, explanations that account for the killings? 


\section{An Alternative Explanation for the Killings}

More specifically, it may be argued that although orders to kill Jews existed, those orders, for all intents and purposes, were superfluous, i.e., they were not really necessary. In the laboratory, obedience pressures were needed to overcome significant moral resistance by Milgram's subjects; without that pressure, most subjects would never have engaged in hurtful behavior that they considered to be wrong or unjust. But the Nazi killers may not have regarded what they did as evil or immoral.

A central, compelling element of Nazi ideology, and an attitude that prevailed among hundreds of thousands of the people of Nazi Germany, was absolute hatred of the Jews. From 1933 on, building on a long history of hatred, vehement and unrelenting anti-Jewish propaganda had vilified and demonized the Jews, depicting them as 'others', as racially inferior, and as the embodiment of vileness and filth; Jews were seen as a disease and 'misfortune', and were blamed for whatever had gone wrong in Germany: war, moral corruption, economic distress, defeat, and postwar humiliation; only through their elimination could health be restored to the German body politic (Dawidowicz 1975; Friedlander 1989; Gordon 1984).

This incitement of contempt and hatred for the Jewish enemy, together with the incessant proclamation of German superiority, could easily have paved the way for the killings (e.g. Fenigstein 1998). Browning (1992, 183), in fact, acknowledged that the men of the Reserve Police were "immersed in a deluge of racist and anti-Semitic propaganda that thoroughly prepared them, ideologically, for the mass murders they were about to perpetrate". If the Nazi perpetrators were "ideologically prepared" to see their Jewish victims as vermin, as less than human, and as hated enemies that threatened their way of life, their destruction could hardly be seen as morally repugnant. A more plausible scenario is that the vast majority of those who did the killing believed it was just and necessary, and would have been willing to kill Jews, even in the absence of orders to do so (e.g. Baumeister 1997; Fenigstein 1998; Goldhagen 1992; 1996).

Thus, before accepting Browning's (and presumably, Milgram's) argument that the same kind of obedience pressure demonstrated in the laboratory was at work in the killings by the Reserve Police, three significant points of departure between Milgram's studies and the events at Józefów need to be examined. All three suggest that although the killings, in some ways, appeared to be a matter of simply following orders, in fact, the perpetrators behaviors were much more strongly motivated by personal antipathy toward the victims and personal beliefs in the value of the killings, than by situational pressures.

Where was conscience? A critical element of the Milgram research was 
that obedience pressures were necessary to compel destructive actions in the face of powerful moral resistance to those actions. As Milgram $(1974,13)$ has argued, the potency of obedience can only be effectively demonstrated when it is opposed by a powerful force, such as the moral imperative against harming an innocent other, that works in the direction of disobedience; in the absence of moral opposition to an action, obedience is unnecessary as an explanation. Thus, Milgram conceptualized both the situation of the laboratory subject, as well as that of the Nazi perpetrator, as a "dilemma posed by the conflict between conscience and authority" (Milgram 1974, 179).

In the laboratory studies, the extreme tension and distress exhibited by virtually all the subjects offered direct evidence of the moral conflict they were experiencing between the demands of a legitimate authority and the demands of conscience. (These reactions, however, should not obscure the basic lesson of the research: despite their moral qualms about hurting an innocent other, the majority of subjects continued to obey the order to do so.) Many subjects, in addition to their emotional ordeal, felt they had acted against their own moral values, voiced disapproval of their actions and denounced them as wrong, and frequently drew attention to the victim's suffering (Milgram 1974, 41).

The operation of similar psychological processes among the men of Reserve Police Battalion 101, then, should be evidenced by similar moral concerns. On the basis of their actions and testimonies, however, such evidence is sorely lacking. There were a few men in the battalion-12 out of a total of almost 500-who, from the beginning, extricated themselves from the impending mass murder; a few more removed themselves from the killing squads only after they had already committed several murders; and some managed on occasion to avoid killing when an opportunity, such as the absence of direct surveillance, arose. In all, Browning (1992) estimated that perhaps 10 to 20 percent sought to evade the killings, once the shootings began. This means, of course, that at least 80 percent of those called upon to shoot helpless victims continued to do so until the last Jew had been killed-and often did so with a sense of relish and bravado that clearly belied the presence of any moral repugnance or distress (e.g. Goldhagen 1996).

Was the reluctance of the few evaders motivated by moral concerns or empathy with their victims' plight? Browning (1992) admitted that in their testimonies, given 20 to 25 years after the fact (and after considerable opportunity for reflection), "those who quit shooting ... overwhelmingly cited sheer physical revulsion as the prime motive, but did not express any ethical principle behind this revulsion" (74). A particularly telling and egregious, but not uncommon, example of the source of the killers' concerns, comes from the testimony of one of the evaders who described the horrifying results of 
the killing action as follows: "The shooters were gruesomely besmirched with blood, brains, and bone splinters; it hung on their clothing" (65; my italics).

A similar picture emerges from a "Wehrmacht neuropsychiatrist who had treated large numbers of Einsatzgruppen for psychological disorders", and reported that although $20 \%$ of the killers experienced such symptoms, about half of them associated it with the "unpleasantness of what they had to do" (Lifton 1986, 15). Thus, based on the reports of Nazi physicians themselves, although some of the killers may have experienced distress, it was not the result of any sense of guilt or remorse.

Browning (1992) hinted at other indications of a sense of moral wrongdoing among the perpetrators, but few of those arguments were compelling. For example, the men of Reserve Police Battalion 101 were often described as bearing an enormous psychological burden, but the precise nature of that burden remains to be explained; their own testimony suggests that it was not the result of principled moral opposition to the destruction of innocent lives, but rather in response to the sheer horror and grisliness of the mass slaughter (which Browning himself acknowledges, and for which there is far more evidence than can be presented here). Browning also described a feeling of "shame" that pervaded the room when the men returned to their barracks, which he claimed was related to a sense of moral transgression. But he also found that "by silent consensus ... the massacre was simply not discussed" by the men (69), making overt indications of such shame difficult to identify.

That these former Nazis failed to express any ethical qualms concerning their participation in the unspeakably brutal murders of innocent, unresisting men, women, and children is especially remarkable considering the circumstances under which these testimonies were given. Speaking to representatives of the criminal justice system in a democratic Germany, these men had powerful motives to express remorse, whether genuine or fabricated, in the hope of mitigating their guilt and perhaps minimizing their punishment. In the absence of any such expression, it is difficult to escape the conclusion that these men simply did not feel that they had performed any morally repugnant actions.

The failure of the Reserve Police to voice any moral opposition to the killing of Jews is critical to the present analysis in several ways: first, it represents a crucial difference between Milgram's subjects, many of whom were reluctant to participate and experienced moral distress over their destructive actions; and the Nazi perpetrators, whose reluctance to kill, if it existed at all, was not a matter of principled conscience, but rather of physical disgust; and second, the absence of moral opposition to the killings not only undermines the necessity, and thus the viability, of obedience as an explanation, it also suggests that the killings were not perceived or understood as immoral acts. Rather, by the time the murders were committed, the victims had already lost 
their humanity, and the killings had no moral force. Moreover, the killings were not only destroying a subhuman enemy, they were also asserting the Nazis' superiority, which may help explain the willingness and dedication of the perpetrators to the killing process.

Was the killing mechanistic? The concept of obedience, as formulated by Milgram, and used by Arendt and Browning, suggests an image of the Nazi executioners as dutiful agents mechanically carrying out the murderous commands of the leader, without hate or malevolence toward their victim. However, much of the Nazis' behavior toward their Jewish victims was anything but detached and emotionless. Arendt's (1963) description of Eichmann has been seriously questioned by a number of critics who point out that Eichmann pursued his goal of shipping as many Jews as possible to the concentration camps with an overzealousness and perseverance that was clearly beyond the call of duty (Robinson 1965). Arendt (1966) herself, in apparent contradiction of her own thesis, offered some horrifying descriptions of the torture and brutality that accompanied the murders committed by the Nazis, clearly acknowledging that there was another face to the Holocaust than that of the dispassionate bureaucrat.

Browning (1992), as well, in describing the behavior of Reserve Police Battalion 101, provided many examples of their penchant for wanton cruelty, barbarism, and sadism toward Jews. In one case, for example, totally naked Jews, preferably old and bearded, were forced to crawl in front of their intended graves and sustain beatings with clubs, before being shot. In several instances, the killers themselves spoke of their routine and unnecessary cruelty (Goldhagen 1996). It should be noted that in the case of the Reserve Police, these perpetrators were not all SS men or ardent supporters of Hitler's regime. They were, for the most part, ordinary Germans, rank-and-file Nazis, who were not, presumably, possessed of any virulent anti-Semitism or obvious inclination toward mass murder. Yet, based on their actions at Józefów and their subsequent testimony, these men were not morally opposed to the Holocaust; when the time came, they proved themselves capable of killing Jews with eagerness, dedication, and zeal. In general, the historical evidence on the spontaneity, initiative, enthusiasm, and pride with which the Nazis degraded, tortured, and killed their victims, is utterly incompatible with the concept of obedience, and simply has no counterpart in the behavior that Milgram observed in his laboratory studies.

Did the killers have a choice? The nature of authority in Milgram's laboratory was not absolute; subjects, presumably, could have quit at any time, and the experimenter had no real power to prevent them from doing so. But surprisingly few subjects exercised that option. There were a number of powerful 'binding' factors-both social and perceptual-that, Milgram argued. Essentially the subjects were locked into a very narrow view of their role, 
a view which, in effect, prevented them from recognizing the possibility of escape. That is, although a real choice existed, many subjects never fully realized or seriously considered the option to leave the experiment.

In ironic contrast, the Nazi perpetrators may have been very much aware of the possibility of escape or avoidance of the killing task. Consider, for example, what happened to those men who were unwilling to participate in the mass murder of Jews? It has been widely assumed (e.g. Baumeister 1997; Miller 1986) that if an SS man refused to carry out a killing order, he himself would be severely punished or killed. This assumption is largely based on repeated and emphatic assertions of this supposed truth by defendants at postwar trials. In addition, given the brutality and fanaticism of the SS, it seemed reasonable to assume that the externally directed terror of the SS could easily be turned inward. But these assumptions are largely mistaken. There is not a single instance on record of harsh punishment ever being used, or even being possible, for disobeying a killing order (Browning 1992; Goldhagen 1985). Thus, the likelihood of anyone in the SS or the Reserve Police suffering punishment for refusing to kill Jews was very small or nonexistent; and if it did occur on rare occasions, it was not widely known. If anything, the killers knew that they were permitted to transfer from the killing units. Himmler himself had issued a written order to that effect with the understanding that only those dedicated to the task should be killing Jews. At some level, Himmler understood that only the most fervent Nazis, those most deeply committed to the cause, could carry out the essential, but difficult task-in the sense of physical, rather than moral, revulsion - of extermination. Failure to carry out the task was not to be punished; it was merely a matter of shame and disgrace for not measuring up to the Nazi ideal.

An important feature of the Browning study is its emphasis on the opportunities that the men of the police battalion had to avoid the task of mass murder. That the perpetrators knew they had a choice of participating or not participating in the killing is made explicit by the testimony of one of the Reserve Police: "It was in no way the case that those who did not want to or could not carry out the shooting of human beings with their own hands could not keep themselves out of this task. No strict control was being carried out here." (Browning 1992, 65) The same point is made by Commander Ohlendorf of Einsatzgruppe D, who testified at Nuremberg that he "had sufficient occasion to see how many men of my Gruppe did not agree to this (killing) order in their inner opinion. Thus I forbade the participation in these executions on the part of some of these men and sent them back to Germany." (Goldhagen 1985) Again, it should be understood that "inner opinion" was not necessarily a matter of conscience. In one case, the SS officer requesting a transfer made it clear that his incapacity to continue killing resulted, not from any principled disapproval of the slaughter, but rather from the physi- 
cal revulsion to the act, rendering him psychologically unfit for the duty. He was deeply ashamed of his inability to "sacrifice himself to the very last for the cause of Germany", but did not want to "disgrace Germany's image" by "presenting the spectacle of one ... who has succumbed to cowardice" (Goldhagen 1985). This Nazi did not oppose the extermination of the Jews out of moral concerns. In fact, every indication was that he believed in the justice of the Einsatzgruppe's task; he simply could not endure the emotional strain of killing.

These observations again seriously challenge the argument that the murderers were at the mercy of unyielding obedience pressures. When ordered to kill innocent, defenseless Jews en masse, dispatching them by machine-gun fire into mass graves, the men drafted into both the mobile killing squads of the Einsatzgruppen and the Reserve Police units, for the most part, complied with the order. But it is difficult to argue that that compliance was due to obedience. The order to kill was not absolutely compelling, and most of the men knew that. Those who were unwilling to kill innocent, defenseless humans could avoid doing so; those who did not extricate themselves from the task, therefore were choosing to participate in the killings. Given that choice, it makes little sense to attribute the behavior of the perpetrators to powerful obedience pressures that supposedly overwhelmed their moral sensibilties; far more compelling is the conclusion that the perpetrators willingly followed orders because they believed that the order to kill innocent Jews was right and just.

\section{Conclusion}

In the face of these arguments, the idea that obedience to authority was an essential element of the perpetrator's behavior is simply untenable. With respect to external appearances, Milgram may have perceived surface similarities in the two events, but as demonstrated earlier, those similarities have no greater weight in the determination of generalizability than equally striking surface differences between the two events.

With respect to more basic processes, Milgram argued that the underlying mechanism of 'obedience to authority' could inform an understanding of the murderous behavior of the Nazi perpetrators. But the research evidence in support of an agentic state- the core psychological transformation that explains the removal of conscience and responsibility-is an extremely tenuous, if not nonexistent, concept.

Most critically damaging to his case, however, is the evidence suggesting that the kind of obedience pressure that is at the heart of Milgram's analysisi.e., authoritarian orders that compelled atrocities, in spite of powerful moral and emotional resistance to those actions-simply did not exist. There is 
little or no evidence of moral opposition or distress by the killers, e.g., a sense of guilt or shame or wrongdoing or concern for the victims. When actions are taken that are not considered to be wrong or immoral, there is no need to invoke external causes, such as obedience pressures, to account for those actions.

There is also considerable evidence that the Nazis' behavior toward the Jewish victims was especially brutal and inhumane. Such excesses cannot be explained by obedience pressure, precisely because they exceeded any orders from above; these cruelties, however, are consistent with a sense of vindictiveness and personal satisfaction that comes out of degrading and destroying the lives of a hated, despicable enemy. Finally, and perhaps most significantly, the great majority of perpetrators had choices. Most of the men who participated in the killings were not compelled or coerced by authority to do so, but rather, chose to do so.

In summary, the overwhelming differences in both surface appearances, and in the underlying theoretical mechanisms that may be inferred, make it difficult to argue that the obedience studies have any relevance to the psychology of the perpetrators. This conclusion, however, should in no way be seen as a critique of the value and insight of Milgram's research; his studies offered a compelling demonstration and analysis of the general human willingness to obey, our capacity for harmdoing, the capriciousness of our sense of personal responsibility, and the weakness of conscience or morality in the face of malevolent authority. As Ross and Nisbett (1991) have observed, his findings "have become part of our ... shared intellectual legacy" (55). But, as has been argued throughout this paper, there is little reason to believe that obedience was a crucial factor for the perpetrators of the Holocaust. Although destructive obedience may exist as a powerful and frightening potential, that does not mean that when innocent people are killed, it is necessarily the result of obedience.

If we compare the Holocaust with Milgram's research in a less analytical, but more prosaic fashion, the differences are brutally clear. Although we may be upset, saddened, even disappointed by the behavior of Milgram's subjects, the terms that are routinely used to describe the horrors of the Holocauste.g., atrocity, inhumanity, hatefulness, wickedness-are simply preposterous in the context of Milgram's studies. Those terms suggest a psychological state that is almost the antithesis of that observed in the lab studies. Milgram's research subjects may have obeyed a malevolent authority, but unlike the Nazi perpetrators, they were not willing participants; they were not responding to malevolent drives within themselves. In contrast, the eagerness and enthusiasm with which so many men participated in the Nazi genocidal program simply cannot be explained as merely a matter of duty and discipline, 
but must instead take full account of the powerful enmity that was operating toward the victims.

In conclusion, the differences are too overwhelming to be dismissed: The fundamental lesson of Milgram's research is an understanding of human weakness, and the frailty of conscience, in the face of malevolent demands by authority to engage in evil that is universally recognized as wrong or immoral; in stark contrast, the fundamental lesson of the Holocaust is an understanding of the human willingness to engage in evil when that evil has been transformed, by social conditioning and state sanction, into something that is right and just, a source of great personal, national, and racial pride, and a matter that has almost nothing to do with conscience, morality, or obedience pressures.

\section{Bibliography}

Arendt, H. (1963), Eichmann in Jerusalem: A Report On the Banality of Evil, New York

- (1966), Introduction to B. Naumann, Auschwitz, New York

Aronson, E./M. Brewer/J. M. Carlsmith (1985), Experimentation in Social Psychology, in: G. Lindzey/E. Aronson (eds.), The Handbook of Social Psychology, (3rd Ed.), New York, 441-486

Askenasy, H. (1978), Are We All Nazis?, Secaucus

Bauman, Z. (1989), Modernity and the Holocaust, Ithaca

Baumeister, R. F. (1997), Evil: Inside Human Violence and Cruelty, New York

Baumrind, D. (1964), Some Thoughts on Ethics of Research: After Reading Milgram's "Behavioral Studies of Obedience", in: American Psychologist 19, 421423

Berger, L. (1983), A Psychological Perspective on the Holocaust: Is Mass Murder Part of Human Behavior?, in R. L. Braham (ed.), Perspectives on the Holocaust, Boston

Blass, T. (1992), The Social Psychology of Stanley Milgram, in L. Berkowitz (ed.), Advances in Experimental Social Psychology 25, New York, 277-329

Browning, C. R. (1992), Ordinary Men, New York

Charny, I. W. (1982), Genocide: The Human Cancer, New York

Darley, J. M. (1992), Social Organization for the Production of Evil, in: Psychological Inquiry 3, 199-218

Dawidowicz, L. S. (1975), The War Against the Jews, New York

Fenigstein, A. (1998), Reconceptualizing the Obedience of the Perpetrators, in: D. Shilling (ed.), Lessons and Legacies of the Holocaust Vol. II, Evanston, 55-84

Friedlander, S. (1989), From Anti-Semitism to Extermination, in: F. Furet (ed.), Unanswered Questions: Nazi Germany and the Genocide of the Jews, New York, 3-31

Gilbert, S. J. (1981), Another Look at the Milgram Obedience Studies: The Role of the Gradated Series of Shocks, in: Personality and Social Psychology Bulletin $7,690-695$ 
Goldhagen, D. (1985), The Cowardly Executioner: On Disobedience in the SS, in: Patterns of Prejudice 19, 19-32

- (1992), The Evil of Banality, in: The New Republic, (July 13-20), 49-52

- (1996), Hitler's Willing Executioners, New York

Gordon, S. (1984), Hitler, Germans, and the "Jewish Question", Princeton

Kelman, H. C./ V. L. Hamilton (1989), Crimes of Obedience: Toward a Social Psychology of Authority and Responsibility, New Haven

Lifton, R. J. (1986), The Nazi Doctors: Medical Killing and the Psychology of Genocide, New York

Mantell, D. M./R. Panzarella (1976), Obedience and Responsibility, in: British Journal of Social and Clinical Psychology 15, 239-245

Milgram, S. (1963), Behavioral Studies of Obedience, in: Journal of Abnormal and Social Psychology 67, 371-178

- (1974), Obedience to Authority: An Experimental View, New York

Miller, A. G. (1986), The Obedience Experiments: A Case Study of Controversy in Social Science, New York

-/B. E. Collins/D. E. Brief (1995), Perspectives on Obedience to Authority: The Legacy of the Milgram Experiments, in: Journal of Social Issues 51, 1-20

Mixon (1979), Understanding Shocking and Puzzling Conduct, in: G. P. Ginsburg (ed.), Emerging Strategies in Social Psychological Research, New York, 155-176

Orne, M. T./C. H. Holland , On the Ecological Validity of Laboratory Deceptions, in: International Journal of Psychiatry 6, 282-293

Robinson, J. (1965), And the Crooked Shall be Made Straight: The Eichmann Trial, the Jewish Catastrophe, and Hannah Arendt's Narrative, New York

Ross, L. D./R. E. Nisbett (1991), The Person and the Situation: Perspectives of Social Psychology, New York

Sabini, J. P./M. Silver (1980), Destroying the Innocent with a Clear Conscience: A Sociopsychology of the Holocaust, in: J. E. Dimsdale (ed.), Survivors, Victims and Perpetrators: Essays on the Nazi Holocaust, Washington, 329-358

Tilker, H. A. (1970), Socially Responsible Behavior as a Function of Observer Responsibility and Victim Feedback, in: Journal of Personality and Social Psychology 14, 95-100 